\title{
Editorial: Food Sovereignty and the Right to Live
}

\author{
WENDY HARCOURT
}

This volume of Development explores how four key environmental concerns - water, gender and fisheries, climate justice and agriculture - are highly political issues at the core of global social justice. The strong message throughout the volume is that the growing media and policy hype around climate change, water and food scarcity, the oil crisis and spiralling consumer costs cannot be divorced from global tensions marked by unfair trade, skewed development, diminished human rights and widening gender inequalities. The climate crisis, the devastating food crisis and rising oil prices indicate present huge obstacles to survival and improving livelihoods.

This issue on the 'Future of Agriculture' brings together the insights of the earlier issues on water for people, gender and fisheries and climate justice and development. The issue is certainly timely as the current global food crisis has forced world attention on the state of agriculture. Agriculture is an issue, as many of the authors here remind us, that policymakers and development banks have been ignoring. But no longer. In April 2008 as Guest Editor Nicola Bullard ${ }^{1}$ was contacting authors, an extraordinary UN expert report laid out the future for agriculture. As two of its senior writers, Marcia Ishii-Eiteman and Lim Li Ching point out in this edition of Last Word the International Assessment of Agricultural Science and Technology for Development (IAASTD, http:// www.agassessment.org, accessed 8 September 2008). Report on agriculture and development demands a radical change in agricultural policy and practice in order to address hunger and poverty, social inequities and environmental sustainability.

The report's central message is that the business-as-usual scenario of industrial farming, input and energy intensiveness, damage to the environment and marginalization of small-scale farmers is no longer tenable. What is required is not only a systematic redirection of investment, funding, research and policy focus towards the needs of small-farmers but also a completely different system of economic and industrial management that takes into account diverse voices and perspectives, particularly those who work the land, poor farmers and in particular women, in their role as farmers, community managers, providers of nutrition, keepers of tradition and leaders of protests.

This journal's articles from Africa, Asia, Latin America, the USA and Europe illustrate well the critical importance of the IAASTD's call to a completely different world system of trade, development and gender relations. The authors - distinguished professors, 
well-known writers, researchers and leaders of civil society and peasant movements - all warn that there is nothing romantic or anti-modern about a call to listen to the farmers, peasants and protesters. Whether writing about agricultural policy in Pakistan, soybean production in Latin America, chicken farming and local markets in the US, pesticides in India, the green revolution in Africa, or the global implications of biofuels and trade and development policy dictated by giant agricultural industries, the authors expose the horrors of globalized capitalist industrial agriculture.

The authors reveal that the victims of global capitalist agriculture are not only the farmers committing suicide by ingesting pesticides, or the millions who die from hunger who are denied their rights to food and dignified livelihoods. As Walden Bello warns, we are all involved in this nightmare marked by financial and environmental crises, social dysfunctions of urban-industrial life, lack of water, energy and growing food insecurity. The angry protests of the farmers' movements, such as the women and men of La Via Campesina, are speaking not only to their governments and to small land owners but to all of us. We are implicated in the catastrophic consequences of today's global agricultural production patterns on community and life. The food crisis is part of the deep financial crisis, the unprecedented climate and environmental crisis which are symptoms of the failure of the neo-liberal global capitalist model where all aspects of society (including food production, health and education) are organized around greed and profit making.

But despite the gravity of such a diagnosis, the journal's message is not one of despair. As Paul Nicholson, a founder of La Via Campesina, states in the interview published here: "The blatant failure of the dominant model opens new spaces to challenge it and to propose alternatives, not only in terms of agrarian policies, but also for more global social changes'. He explains how media and modern communication technologies have allowed for greater mobilization and protest forcing governments to question technological solutions such as agrofuels and corporate domination and to push governments to rethink 440 the wisdom of trade and exports as against domestic production. The message that growing social and economic disparities, environmental degradation and global food crisis stem directly from the free-market restructuring of agriculture is out, and more and more people are listening and wanting to take action.

Raj Patel in his lead article and recent bestselling book Stuffed and Starved underlines that taking action to end the food crisis plays out in different ways depending on where you live. For most people in urban environments in the North, it is about finding out just what we are eating, where it comes from and where it is processed. He points out that such 'choices' are 'far stranger and more unnatural than we thought' because 'at every step of the way they have been attended by food corporations trying to make money out of our choices' (Patel, 2008: 290). It is about eating less and eating better. It is about ending commercialization of food, and eating locally, the slow food movement in Italy being one example of what consumers together with local growers can achieve. In the South it is too often about survival, having access to land, food and security. It is about the violent protests that push southern governments to stand up to powerful northern interests and bring, for example, the WTO negotiations to a halt. In either case he suggests that, 'unless you're a corporate food executive, the food system isn't working for you. Around the world, farmers and farm workers are dying ... through processed food consumers are engorged and intoxicated' (Patel, 2008: 293).

Nevertheless, we can reshape the food and agricultural system. Clearly we are not talking about simply better development policy to address technical or economic problems. Sadly, even on its own terms, the current response of the intergovernmental system, the Millennium Development Goals to halve global poverty by 2015, is failing to address today's social, economic and environmental crises.

To start with, Development readers should take note of the in-depth analysis provided in the articles to learn more about the worrying facts that make us deeply question just what is driving our present global food system: nutrition and life or profit for a few. It is salutary to realize the depth 
of the crises and just how much we are not in control of our economies, nutrition and health. But it is equally important to learn the other strong message of the journal that there is a shared vision that addresses the abuses of the global industrialized agricultural system.

That message is about all of us claiming food sovereignty, or peoples' rights to define their agricultural and food policy, including the rights of farmers and peasants, the rights of consumers and the rights of women, who play a major role in agricultural production and food. Food sovereignty requires major changes, from changing our tastes, eating locally and seasonally, supporting locally owned business, along with a profound and comprehensive change in rural policies based on living wages for all, rights and support for a sustainable architecture of the global food system, as well as recognizing and providing restitution for the injustices of the past (Patel, 2008: 302-317).

We can take courage from Nicholson's belief that people will start developing their own alternatives just because it will become a necessity. He speaks of more and more people in the North spontaneously joining the struggle of Via Campesina, because they feel part of this struggle for life'. He and other proponents of food sovereignty bring strength and confidence that across the world it is possible to build a new society that sustains life and health rather than greed and fear.

\section{Note}

1 Special thanks to Nicola Bullard for putting together this issue as Guest Editor.

\section{References}

Patel, Raj (2008) Stuffed and Starved, London: Portobello Books.

The International Assessment of Agricultural Science and Technology for Development (IAASTD) on Agriculture and Development. Available online. 